\title{
The quantification of respect for selected core labour standards: towards a social development index?
}

\author{
Working Paper No. 71
}

\author{
Ludo Cuyvers and \\ Daniel Van Den Bulcke*
}

Policy Integration Department

Statistical Development and Analysis Group

International Labour Office

Geneva

July 2005

* University of Antwerp

Working papers are preliminary documents circulated to stimulate discussion and obtain comments 
Copyright $@$ International Labour Organization 2005

Publications of the International Labour Office enjoy copyright under Protocol 2 of the Universal Copyright Convention. Nevertheless, short excerpts from them may be reproduced without authorization, on condition that the source is indicated. For rights of reproduction or translation, application should be made to the Publications Bureau (Rights and Permissions), International Labour Office, CH-1211 Geneva 22, Switzerland. The International Labour Office welcomes such applications.

Libraries, institutions and other users registered in the United Kingdom with the Copyright Licensing Agency, 90 Tottenham Court Road, London W1T 4LP [Fax: (+44) (0)20 7631 5500; email: cla@cla.co.uk], in the United States with the Copyright Clearance Center, 222 Rosewood Drive, Danvers, MA 01923 [Fax: (+1) (978) 750 4470; email: info@copyright.com] or in other countries with associated Reproduction Rights Organizations, may make photocopies in accordance with the licences issued to them for this purpose.

ISBN 92-2-118153-7 (print)

ISBN 92-2-118154-5 (web/pdf).

First published 2005

Cover:

The designations employed in ILO publications, which are in conformity with United Nations practice, and the presentation of material therein do not imply the expression of any opinion whatsoever on the part of the International Labour Office concerning the legal status of any country, area or territory or of its authorities, or concerning the delimitation of its frontiers.

The responsibility for opinions expressed in signed articles, studies and other contributions rests solely with their authors, and publication does not constitute an endorsement by the International Labour Office of the opinions expressed in them.

Reference to names of firms and commercial products and processes does not imply their endorsement by the International Labour Office, and any failure to mention a particular firm, commercial product or process is not a sign of disapproval.

ILO publications can be obtained through major booksellers or ILO local offices in many countries, or direct from ILO Publications, International Labour Office, CH-1211 Geneva 22, Switzerland. Catalogues or lists of new publications are available free of charge from the above address, or by email: pubvente@ilo.org

Visit our website: www.ilo.org/publns 


\section{The quantification of respect for selected core labour standards: towards a social development index}

\section{Contents}

Preface

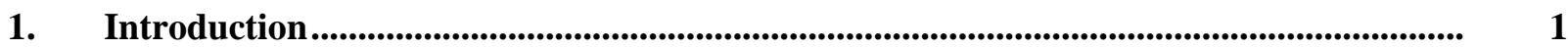

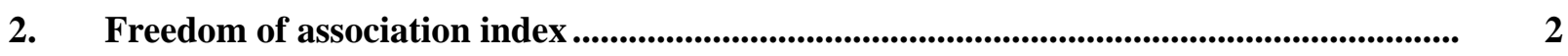

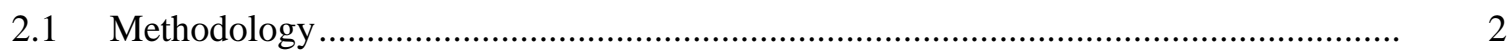

$2.2 \quad$ Formula of the Freedom of Association Index ....................................................... 3

2.2.1 The Formal Freedom of Association Index (FFAI) Formula .............................. 4

2.2.2 The Real Freedom of Association Index (RFAI) Formula .................................. 4

2.2.3 The Freedom of Association Index (FAI) Formula .......................................... 6

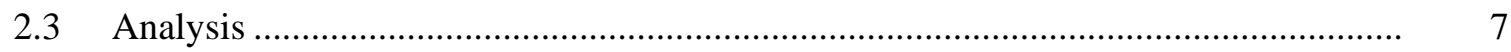

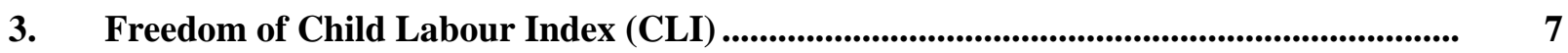

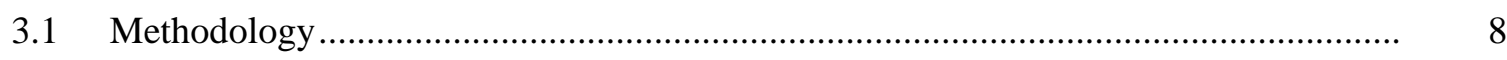

3.1.1 Formal Child Labour Index (FCLI) Formula ………........................................ 8

3.1.2 Real Child Labour Index (RCLI) Formula ........................................................ 10

3.2 The (Composite) Child Labour Index (CLI) Formula ................................................. 11

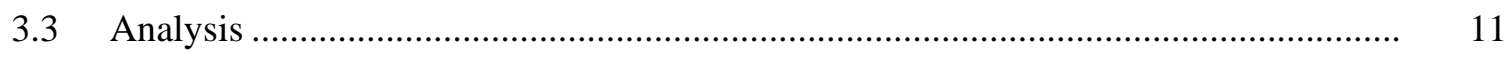

4. Freedom of Gender Discrimination Index (GDI) ............................................................... 12

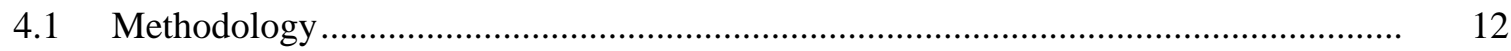

4.2 Gender Discrimination Index (GDI) Formula ……................................................... 13

4.2.1 Formal Gender Discrimination Index (FGDI) Formula …................................. 13

4.2.2 Real Gender Discrimination Index (RGDI) Formula ........................................ 15

4.2.3 The (Composite) Gender Discrimination Index (GDI) Formula ........................ 16

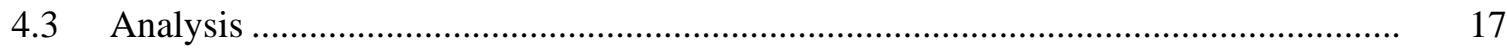

5. The Forced Labour Index ...................................................................................................................... 17

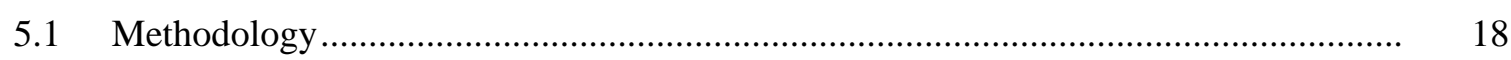

5.1.1 The Formal Forced Labour Index (FFLI) ........................................................ 18

5.1.2 The Real Forced Labour Index (RFLI) ....................................................... 18

5.1.3 The (Composite) Forced Labour Index ............................................................. 21

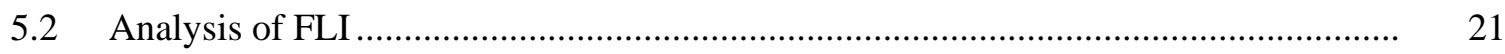

6. Sensitivity analysis ............................................................................................................... 22

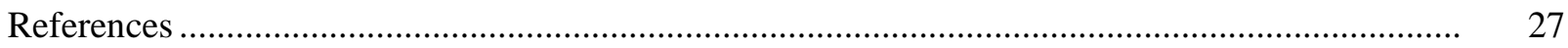

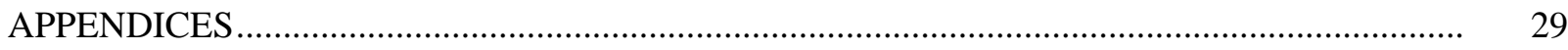




\title{
Preface
}

In September of 2004, the Policy Integration Department organized a technical staff seminar bringing together leading experts within and outside the ILO on so-called "qualitative" indicators of international labour standards. Recent years have seen a rapidly growing interest in the construction and use of such qualitative indicators among both researchers and policy-makers. This growth is arguably attributable to several factors, such as debates on the economics of labour standards, growing interest in socially responsible investing, and the recognition that statistics that are commonly used as quantitative indicators of labour standards are of limited value in capturing many aspects of labour standards and their application. Qualitative indicators of labour standards and worker rights, while numerical, address things that are intrinsically more qualitative in nature and are based, for example, on methods such as grading by experts and the coding of legislation and other textual sources. The rapidly growing interest in such qualitative indicators raises a number of questions about comparative methods for the construction of these indicators as well as the appropriateness of particular methods for particular uses, and these questions were the focus of the seminar.

"The quantification of respect for selected core labour standards: towards a social development index?" was one of the papers presented at the seminar. In this paper, Ludo Cuyvers and Daniel Van Den Bulcke present their method of constructing country-level indicators for each of the ILO's four "fundamental rights at work" as regards freedom of association and collective bargaining rights, child labour, forced labour and inequality in employment. Each of these four indices is itself made up of the authors call an index of "formal compliance" as well as an index of "real compliance." The former largely addresses ratification of relevant ILO Conventions as well as the regularity of countries' reporting to the ILO regarding compliance with these Conventions. The indices of "real compliance" use a wide range of information sources, both quantitative and qualitative. Regarding freedom of association and collective bargaining rights, for example, the authors code textual sources regarding reported incidents of violations against trade union members and leaders, government interference and legal limitations on these rights. Regarding child labour, the index of "formal compliance" codes countries's legislation related to child labour and the index of "real compliance" makes use of data on the economic activity rate of 10 to 14 year olds. Regarding inequality in employment, the authors' focus on gender inequality, with the "real compliance" index makes use of such data as gender inequality in education enrollment and gender representation in professional and wage employment. Regarding forced labour, the "real compliance" index codes textual sources for the number of forms and the severity of reported incidents of forced labour.

\author{
Peter Peek \\ Manager \\ Statistical Development and Analysis Group \\ Policy Integration Department \\ International Labour Office
}

July 2005 
1. Introduction

More and more indices to measure and monitor aspects of economic and social life in different countries have been introduced and are now widely used. One of the first such indices, allowing an international comparison by several organisations, was the Human Development Index of UNDP (UNDP, 2003). Other indices were constructed by academics and consultants in order to measure international competitiveness (e.g. IMD, 2004), economic freedom (Heritage Foundation, 2004), corruption (e.g. for Asia: Political and Economic Risk Consultancy, 2001), comparative purchasing power of currencies (e.g. The Economist, 2004), etc. Yet, no such index has been proposed to measure social development vis-à-vis the benchmark of international social standards.

By setting up recommendations and conventions, the ILO promotes an international environment for labour and labour conditions which is in accordance with specified international standards and therefore intends to create a level playing field in social competition among nations. Eight fundamental standards of the rights of human beings at the working place have been identified. These standards have to be complied with, irrespective of the levels of development of individual Member States, and are called core labour standards. These core labour standards are:

1. Freedom of Association and Protection of the Right to Organize Convention, 1948 (No. 87), C-87 for short

2. Right to Organize and Collective Bargaining Convention, 1949 (No. 98), C-98 for short

3. Forced Labour Convention, 1930 (No. 29), C-29 for short

4. Abolition of Forced Labour Convention, 1957 (No. 105), C-105 for short

5. Discrimination (Employment and Occupation) Convention, 1958 (No. 111), C-111 for short

6. Equal Remuneration Convention, 1951 (No. 100), C-100 for short

7. Minimum Age Convention, 1973 (No. 138), C-138 for short

8. Worst Forms of Child Labour Convention, 1999 (No. 182), C-182 for short.

In previous research (Wermenbol, Cuyvers, and Van Den Bulcke, 1998; Cuyvers, Van Den Bulcke and Wijaya, 2001), we have suggested ways to quantify countries' compliance with some of these core standards, as well as to judge the country's capacity and willingness to adopt and comply with the core standards. Although in Wermenbol, Cuyvers and Van Den Bulcke (1998) it was attempted to aggregate the various sub-indices into a social development index, no such exercise was made in Cuyvers, Van Den Bulcke and Wijaya (2001).

The present paper will give an overview of the methodology applied in this quantification of respect for ILO core labour standards, whereas the issue of the capacity of countries to adopt, implement and comply with such standards is left out of the picture for brevity's sake. Compared to Cuyvers, Van Den Bulcke and Wijaya (2001) no update of the quantitative and qualitative information used is carried out, however. 
We will concentrate on the freedom of association and collective bargaining, the freedom from child labour, the freedom from gender discrimination, and the freedom from forced labour. For each core labour standard the individual countries' status is measured using an index between 0 and 1 , which is constructed, by calculating weighted averages of various aspects of the ratification and compliance record of the countries.

In our attempt to measure the core labour standards' status of countries, a distinction has been made between 'formal' and 'real' compliance. The 'formal' social development index of a country refers to any official acceptance toward the core labour standards which takes the form of ratification of these conventions and the consequent reporting. The 'real' social development index takes factual information into account, and refers to the extent of compliance of the mentioned standards, or similar practices as referred by the standards whether the country ratified the standards or not.

In constructing formulas for assessing respect for selected core labour standards, we will use 1 (or $100 \%$ ) as maximum compliance. This implies that any aspect or element relating to the lack of respect should diminish this maximum index, so that the index becomes lower than 1. It is as if a "fine" is applied to the maximum score. If various aspects or elements have to be taken into account, they should be weighted using weighing coefficients. As will be seen in the formulas that are put forward in the following sections, this procedure often becomes very tedious and complicated. This seems to be the price that has to be paid for comprehensiveness.

\section{Freedom of association index}

Freedom of Association (FAI) in a narrow sense encompasses the freedom to establish trade unions as well as the protection of this right of association and more or less refers to the contents of C-87. Free association in a broad sense includes not only convention C-87 and the right to strike but also the right to collective bargaining as is included in social standard C-98. At present, there is a discussion about whether or not to include the right to strike in the notion 'freedom of association', since this former right is not explicitly mentioned in C-87. In this report it was decided to include the right to strike, however.

The FAI is constructed to measure the degree of formal and real respect of a country with regard to the ILO-conventions C-87 and C-98. The degree of formal confiance a country has with respect to C-87 and C-98 is measured by whether or not the country ratified the C-87 and C-98. The degree of real respect a country has with regard to C-87 and C-98 is measured by the type and number of violations of the contents of these conventions.

\section{$2.1 \quad$ Methodology}

The construction of the Freedom of Association Index is confronted by some constraints as quantitative data are rarely available. Official records of convention ratification and the reporting history of countries will be used and analyzed in order to determine the formal element of a country's compliance. Whenever a country did not ratify a specific convention, the country legislation compatibility towards the convention substance was taken into consideration to substitute for the lack of ratification.

The other element of the Freedom of Association Index is the degree of real respect of a country for the provisions of conventions C-87 and C-98 on the basis of the number of reported violations. Violations such as the number of persons murdered, wounded, arrested or dismissed were classified as 'reported violations' (category A). Whether or not a government intervenes or interferes in trade unions' activities were categorized as 'government interference' (category B). Finally, other kinds of limitations (e.g. legal 
limitations) with regard to free trade unions were categorized as 'legal and other limitations' (category C). These three categories of violations originated from their frequent and systematic occurrence in the annual ICFTU reports as well as in the Human Rights Practices reports from the US Department of State.

\subsection{Formula of the Freedom of Association Index}

The Freedom of Association Index (FAI) is based on two elements: the Formal Freedom of Association Index (FFAI) and the Real Freedom of Association Index (RFAI). The components of these elements are the following:

\section{FFAI: Formal Free Association Index}

- Ratification of C-87 and C-98

- Reports requested and received (art. 19) on C-87 \& C-98

\section{RFAI: Real Free Association Index}

- Category $\mathrm{A}$ : the reported number of violations vis-à-vis trade union members/leaders

- $\quad$ Number of murders

- $\quad$ Number of wounded

- $\quad$ Number of arrests

- $\quad$ Number of dismissals

- Category B: government interference

- Category C: legal limitations, regarding

- Formation and/or adherence to an independent union of their own choice

- Formation and/or adherence to a (con)federation

- Affiliation with an international trade union organization

- $\quad$ Right to strike

- $\quad$ Right to collective bargaining

- $\quad$ Protection against anti-union discrimination 


\section{The Formal Freedom of Association Index (FFAl) Formula}

Was constructed, given the components of the FFAI, the following formula:

$$
\text { FFAI }_{j}=1-\left[\left(\omega_{87} \delta_{87 \mathrm{j}}-\omega_{\operatorname{art} 19} \delta_{\delta 87 \mathrm{j} j}\right)+\left(\omega_{98} \delta_{98 \mathrm{j}}-\omega_{\operatorname{art} 19} \delta_{\delta 98 \mathrm{j} j}\right)\right]
$$

with

$\omega_{87}=$ weighing coefficient $(0.5)$ for convention 87

$\omega_{98}=$ weighing coefficient $(0.5)$ for convention 98

$\omega_{\text {art 19}}=$ weighing coefficient $(0.125)$ for article 19 of the ILO constitution

$\delta_{87 \mathrm{j}}=$ a dummy variable which equals 1 in case country j did not ratify convention 87 and equals 0 in case it did ratify the convention

$\delta_{98 \mathrm{j}}=$ a dummy variable which equals 1 in case country j did not ratify convention 98 and equals 0 in case it did ratify the convention 98

$\delta_{887 \mathrm{j}}=\mathrm{a}$ dummy variable which equals 1 in case the dummy variable $\delta 87 \mathrm{j}$ was 1 (which means that country j did not ratify $\mathrm{C}-87$, hence article 19 is applicable) AND in case the non-ratifying country concerned though did send their report stating their legislation and practice regarding $\mathrm{C}-87$. On the other hand, $\delta_{\delta 87 \mathrm{j} j}$ equals 0 in case the dummy variable $\delta 87 \mathrm{j}$ was 0 (which means that country j did ratify $\mathrm{C}-87$ and hence article 19 is not applicable.

$\delta_{\delta 98 \mathrm{j} j}=$ a dummy variable which equals 1 in case two conditions mentioned below are met: First, in case the other dummy variable $\delta 98 \mathrm{j}$ equals 1 as well (meaning that country $\mathrm{j}$ did not ratify convention 98), article 19 of the ILO constitution is applicable. Secondly, in case the non-ratifying country $\mathrm{j}$ handed in its report stating their legislation and practice regarding C-98, the dummy variable $\delta_{\delta 98 \mathrm{j} j}$ equals 0 in case the dummy variable $\delta_{98 \mathrm{j}}$ amounted to 0 (which means that country $\mathrm{j}$ did already ratify the convention concerned) and thus article 19 is not applicable. The question whether or not a non-ratifying country did send its report then becomes irrelevant.

Consider the situation of China in 2001 as based on the data used in Cuyvers, Van Den Bulcke and Wijaya (2001), a country which had ratified neither C-87 nor C-98, and was not sending in its reports. In this case, the FFAI $=0$. This can be compared with Brazil, which had only ratified C-98, but is reporting on that convention. If Brazil, not having ratified C-87, would report on that convention, a different situation would arise. In a matter of fact, the "fine" for not ratifying - $\omega_{87} \delta_{87 \mathrm{j}}$ with $\boldsymbol{\omega}_{87}=\mathbf{0 . 5}$ and $\boldsymbol{\delta}_{87 \mathrm{j}}=\mathbf{1}$ - would be reduced with $\boldsymbol{\omega}_{\text {art }}{ }_{19} \delta_{\delta 87 \mathrm{j} j}$, where $\boldsymbol{\omega}_{\text {art } 19}=\mathbf{0 . 1 2 5}$ and $\delta_{\delta 87 \mathrm{j}}=\mathbf{1}$. In reality, however, Brazil was not reporting on $\mathrm{C}-87$ and therefore $\boldsymbol{\delta}_{\mathbf{8 8 7} \mathbf{j}} \mathbf{j}=\mathbf{0}$. Thus, applying the FFAI to Brazil would lead to the following result: $1-\left[\left(0.5^{*} 1-0.125^{*} 0\right)+\left[\left(0.5^{*} 0-0.125^{*} 0\right)\right.\right.$.

\subsubsection{The Real Freedom of Association Index} (RFAI) Formula

To establish RFAI, basically qualitative data have to be transformed into quantitative measures. Therefore scores are attached to various possible situations as reported in the sources that are available. The scores will be higher, the more severe is the violation, as the "fine" applied to such violation should diminish the RFAI. It goes without saying that this introduces a substantial degree of arbitrariness, especially in cases where no information is available. In such cases it was decided to opt for a "fine" equal to 0.3, compared to a 
maximum "fine" of 1 . The lack of information is therefore considered to be equivalent in most cases to information withheld for further scrutiny. The degree of arbitrariness is the price to be paid for quantification. The following scores are applied:

\section{Category A 'Number of reported violations'}

\begin{tabular}{|c|c|c|c|c|c|c|c|}
\hline \multicolumn{2}{|l|}{ Number of murders } & \multicolumn{2}{|c|}{ Number of wounded } & \multicolumn{2}{|l|}{ Number of arrests } & \multicolumn{2}{|c|}{ Number of dismissals } \\
\hline Interval & Score & Interval & Score & Interval & Score & Interval & Score \\
\hline 0 & 0 & 0 & 0 & 0 & 0 & 0 & 0 \\
\hline 1-5 (incl. 5) & $1 / 5$ & 1-10 (incl. 10) & $1 / 5$ & 1-25 (incl. 25) & $1 / 5$ & 1-100 (incl.100) & $1 / 5$ \\
\hline 5-10 (incl. 10) & $2 / 5$ & 10-20 (incl.20) & $2 / 5$ & 25-50 (incl. 50) & $2 / 5$ & $\begin{array}{c}100-250 \text { (incl. } \\
250 \text { ) }\end{array}$ & $2 / 5$ \\
\hline 10-15 (incl. 15) & $3 / 5$ & 20-30 (incl.30) & $3 / 5$ & 50-75 (incl. 75) & $3 / 5$ & $\begin{array}{c}\text { 250-400 (incl. } \\
400 \text { ) }\end{array}$ & $3 / 5$ \\
\hline 15-20 (incl. 20) & $4 / 5$ & $30-40$ (incl. 40) & $4 / 5$ & 75-100 (incl. 100) & $4 / 5$ & $\begin{array}{c}\text { 400-550 (incl. } \\
550 \text { ) }\end{array}$ & $4 / 5$ \\
\hline$>20$ & 1 & $>40$ & 1 & $>100$ & 1 & $>550$ & 1 \\
\hline N.A. & 0,3 & N.A. & 0,3 & N.A. & 0,3 & N.A. & 0,3 \\
\hline
\end{tabular}

\section{Category B 'Government intervention / interference'}

\begin{tabular}{llc}
\hline SYMBOL & MEANING & SCORE \\
\hline $\mathrm{Y}$ & government interference & 1 \\
$\mathrm{~N}$ & free of government interference & 0 \\
N.A. & data not available & 0,3 \\
\hline
\end{tabular}

\section{Category C 'Legal limitations'}

\begin{tabular}{llc}
\hline SYMBOL & MEANING & SCORE \\
\hline NONE & no legal obstacles & 0 \\
S & legal obstacles for a specific sector or a small number of sectors & $1 / 3$ \\
APU/APR/A(..) & $\begin{array}{l}\text { legal obstacles which exist in all public (APU) or all private (APR) sectors. In } \\
\text { case of a legal limitation that altogether amounts to the overall public or private } \\
\text { sector, which is spread out over several public and private sectors, the symbol }\end{array}$ & $2 / 3$ \\
& A(..) is used & 1 \\
A & legal limitations exist in all sectors of the economy & 0,3 \\
N.A. & data not available & \\
\hline
\end{tabular}


After having classified the original information into the three types of violations and subsequently converted them into numeral data by attributing scores ranging from zero to one and finally ascribing to them the more or less arbitrary weighing coefficients (see further), the RFAI can be calculated by using the following formula:

$\operatorname{RFAI}_{\mathrm{j}}=1-\left(\omega_{\mathrm{rv}} \mathbf{R V}+\omega_{\mathrm{gi}} \delta_{\mathrm{gij}}+\omega_{\mathrm{ll}} \mathbf{L L}\right)$

with

$\omega_{\mathrm{rv}}=$ weighing coefficient $(0.4)$ for the number of reported violations

$\omega_{\mathrm{gi}}=$ weighing coefficient $(0.3)$ for government interference

$\omega_{11}=$ weighing coefficient $(0.3)$ for legal limitations

$\mathrm{RV}=$ score of the number of reported violations for the 4 different sub-categories

$\delta_{\mathrm{gij}}=\mathrm{a}$ dummy variable with respect to government intervention / interference amounting to 1 in case country $\mathrm{j}$ interferes and to 0 in case of absence of intervention or interference

$\mathrm{LL}=$ legal limitations in 5 sub-categories

The calculation of the RFAI can be illustrated by the following examples based on the data used in Cuyvers, Van Den Bulcke and Wijaya (2001).

Belgium's RFAI $=1$, as there are no violations reported and, hence, $\mathrm{RV}=0, \delta_{\mathrm{gij}}=0$ and $\mathrm{LL}=0$. Consider, however, Argentina with a $\mathrm{RV}=0.28$. Based on the 2001 data, this figure is arrived at by counting the number of murders (5), the number of wounded (28), the number of arrests $(0)$ and the number of dismissals $(0)$, and applying the attributed score according to the severity of the violation, and the weights for the four types of violations. The penalty score for murders up to five is 0.2 and that for between 21 and 30 wounded, 0.6. The scores for the arrests and the dismissals is evidently 0 . By applying the weights, which are 0.5 for murders, 0.3 for wounded, 0.1 for arrests and 0.1 for dismissals, we arrive at: $\mathrm{RV}=$ $[(0.5 * 0.2)+(0.3 * 0.6)+(0.1 * 0)+(0.1 * 0)]$. In addition, as government intervention in labour issues is reported in Argentina, $\delta_{\mathrm{gij}}=1$. Argentina's $\mathrm{LL}=0.3$, as information is not available. Therefore: RFAI in Argentina's case is:

$\mathrm{RFAI}=1-[(0.4 * 0.28)+(0.3 * 1)+(0.3 * 0.3)]=1-[0.112+0.3+0.09]=0.498$.

\subsubsection{The Freedom of Association Index (FAI)} Formula

Eventually, a composite Freedom of Association Index (FAI) is composed, by weighing the FFAI and the RFAI per country, as follows:

FAI $_{j}=\omega_{\mathrm{f}} \mathrm{FFAI}_{\mathrm{j}}+\omega_{\mathrm{r}}$ RFAI $_{\mathrm{j}}$

with

$\omega_{\mathrm{f}}=$ weighing coefficient $(0.3)$ for the FFAI

$\omega_{\mathrm{r}}=$ weighing coefficient $(0.7)$ for the RFAI 
Again, consider Argentina with a FFAI=1 (Argentina ratified C-87 and C-98 in 2001, and reported in accordance with Art. 19) and a RFAI $=0.498$, which leads to:

$\mathrm{FAI}=(0.3 * 1)+(0.7 * 0.498)=0.3+0.3486=0.6486$

\subsection{Analysis}

Appendix 1 shows for a selected number of countries the FFAI, the RFAI and the FAI. Table 1 shows the Top 5 worst and the Top 5 best "performers" in terms of freedom of association, based on the calculations of Cuyvers, Van Den Bulcke and Wijaya (2001).

Table 1: The top 10 worst and best "performers" in terms of their FAl score, 1999

Top 10 worst FAl scores

1. Colombia $(0.40)$

2. Thailand (0.45)

3. $\operatorname{Morocco}(0.47)$

4. Armenia, Kiribati (0.49)

5. Rep. Korea (0.58)

6. China (0.59)

7. Nepal (0.61)

8. Equatorial Guinea (0.62)

9. Kenya (0.63)

10. India, Mauritania (0.64)

\section{Top 10 best FAl scores}

1. Japan, Germany (1.00)

2. Israel, Namibia (0.99)

3. United Kingdom, Slovakia (0.98)

4. Guyana (0.97)

5. Bangladesh, South Africa (0.96)

6. Switzerland (0.94)

7. Norway (0.92)

8. Russia Federation (0.91)

9. Nicaragua (0.88)

10. Peru $(0.87)$

\section{Freedom of Child Labour Index (CLI)}

The predominant objective of convention C-138 is the complete abolition of child labour and the gradual elevation of the minimum age for admission to the labour market in such a way that children have reached their full physical and mental development before they are employed. At the moment the age limit is set at 15 years. As already mentioned this is not all that fixed and inflexible as presumed some relaxation measures have been included (accepted). Besides, there are a number of vague statements and adjectives like 'insufficiently' developed educational facilities, 'light work', 'adequate' instruction or training, etc. mentioned in $\mathrm{C}-138$ that make such provisions a matter of interpretation. In addition to C-138, the so-called Worst Forms of Child Labour Convention C-182 was adopted in 1999. 


\subsection{Methodology}

In order to measure the formal respect of C-138 and C-182, a Child Labour Index (CLI) is constructed. Following the same procedure as in the construction of the Freedom of Association Indes, the CLI consists of two components, viz. the Formal Child Labour Index and the Real Child Labour Index (RCLI), appropriately weighted.

\subsubsection{Formal Child Labour Index (FCLI) Formula}

While referring to the procedure that was used to set up the FFAI in the following types of violations of $\mathrm{C}-138$ are considered. Regarding $\mathrm{C}-182$, the ratification records of the countries at issue are taken into account.

\begin{tabular}{|c|c|}
\hline Type A : violation by non-ratification & In case of: \\
\hline "Strict requirement" & Non-ratification of C-138 \\
\hline "Flexible requirement" & Ratification of less than 4 preceding conventions \\
\hline Type B.: violation by a lower stipulated minimum age & In case of: \\
\hline \multicolumn{2}{|l|}{ Type B.1. : Violation by lower stipulated basic minimum age } \\
\hline "Strict requirement" & Basic minimum age of $<15 \mathrm{yr}$. \\
\hline "Flexible requirement" & Basic minimum age of $<14 \mathrm{yr}$. \\
\hline $\begin{array}{l}\text { Type B.2 : violation by a lower stipulated minimum age for light } \\
\text { work }\end{array}$ & Minimum age $<13 \mathrm{yr}$. \\
\hline \multicolumn{2}{|l|}{$\begin{array}{l}\text { Type B.3 : violation by a lower stipulated minimum age for } \\
\text { hazardous work }\end{array}$} \\
\hline "Strict requirement" & Minimum age $<18 \mathrm{yr}$. \\
\hline "Flexible requirement" & Minimum age $<16$ yr. \\
\hline $\begin{array}{l}\text { Type B.4 : violation by a lower age than the end of compulsory } \\
\text { education }\end{array}$ & Minimum age < compulsory education age \\
\hline
\end{tabular}

The formula that is used to measure the degree of formal respect of C-138, uses the same approach as was pointed out in the discussion of the use of weights and scores in the construction of the FFAI, i.e. :

$\operatorname{FCLI}_{\mathrm{j}}=1-\left[\left(\delta_{138 \mathrm{j}}\left(\omega_{138} \delta_{4 \mathrm{j}}+0.5 \omega_{138}\left(1-\delta_{4 j}\right)\right)\right)+\left(\delta_{\mathrm{bsj}}\left(\omega_{\mathrm{bs}} \delta_{\mathrm{bfj}}+0.5 \omega_{\mathrm{bs}}\left(1-\delta_{\mathrm{bfj}}\right)\right)\right)+\left(\omega_{1}\right.\right.$ $\left.\left.\delta_{\mathrm{lj}}\right)+\left(\delta_{\mathrm{hsj}}\left(\omega_{\mathrm{hs}} \delta_{\mathrm{hfj}}+0.5 \omega_{\mathrm{hs}}\left(1-\delta_{\mathrm{hfj}}\right)\right)\right)+\left(\omega_{\mathrm{e}} \delta_{\mathrm{ej}}\right)+\left(\omega_{182} \delta_{182}\right)\right]$

with

FCLI $_{j}=$ formal child labour index of country $\mathrm{j}$

$\delta_{138 \mathrm{j}}=\mathrm{a}$ dummy variable that equals 1 in case of formal violation of C-138 and equals 0 in case of formal respect regarding ratification of $\mathrm{C}-138$

$\delta_{4 \mathrm{j}} \quad=$ a dummy variable that equals 0 in case country $\mathrm{j}$ has ratified at least 4 previous conventions on minimum age and equals 1 in case country $\mathrm{j}$ has not done so 
$\delta_{\text {bsj }}=$ a dummy variable that equals 0 in case country $\mathrm{j}$ respects the basic minimum age set at 15 years as stated in C-138 and equals 1 in case it is set at a lower age

$\delta_{\mathrm{bfj}} \quad=$ a dummy variable that equals 0 in case country $\mathrm{j}$ has a basic minimum age of 14 years ( instead of 15 ) and equals 1 in case it is set a lower age

$\delta_{\mathrm{lj}} \quad=$ a dummy variable that equals 0 in case country $\mathrm{j}$ has, regarding light work, a minimum age of at least 13 years and equals 1 in case country $\mathrm{j}$ has a lower minimum age

$\delta_{\mathrm{hsj}} \quad=$ a dummy variable that equals 0 in case country $\mathrm{j}$ has, regarding hazardous work, a minimum age of at least 18 years and equals 1 in case a country has set a lower one.

$\delta_{\mathrm{hfj}}=$ a dummy variable that equals 0 in case country $\mathrm{j}$ has, regarding hazardous work, set their minimum age at 16 or 17 , and equals 1 in case it has set a lower age limit

$\delta_{\mathrm{ej}} \quad=$ a dummy variable that equals 0 in case country $\mathrm{j}$ has, regarding compulsory education, set an age limit that at least equals the country' s basic minimum age and equals 1 in case it is lower

$\delta_{182 \mathrm{j}}=$ a dummy variable that equals 0 in case country $\mathrm{j}$ has ratified C-182 and 1 in case of non ratification

$\varpi_{138}=$ weighing coefficient $(0.1)$ for $\mathrm{C}-138$

$\varpi_{\mathrm{bs}} \quad=$ weighing coefficient $(0.1)$ for the stricter standard regarding the basic minimum age ( 15 years )

$\Phi_{1} \quad=$ weighing coefficient $(0.1)$ for a minimum age of 13 years regarding light work

$\varpi_{\mathrm{hs}} \quad=$ weighing coefficient $(0.1)$ for the stricter minimum age standard ( i.e. 18 years) regarding hazardous work

$\varpi_{\mathrm{e}} \quad=$ weighing coefficient $(0.1)$ for the minimum age regarding compulsory education (that should at least equal to the country's stipulated basic minimum age limit).

$\omega_{182}=$ weighing coefficient $(0.5)$ for $\mathrm{C}-182$.

It is important to stress that the weighing coefficients add up to one, with the sum of the weighing coefficients applied to provisions of C-138 representing half of that, and the weighing coefficient relating to formal respect for $\mathrm{C}-182$ being 0.5 .

The rationale for the first part of the formula:

$\left(\delta_{138 \mathrm{j}}\left(\omega_{138} \delta_{4 \mathrm{j}}+0.5 \omega_{138}\left(1-\delta_{4 \mathrm{j}}\right)\right)\right.$

is to increase the penalty or "fine" (i.e. a larger deduction from 1, the maximum FCLI) in case a country has ratified previous conventions, but not C-138. In such a case $\delta_{138 \mathrm{j}}=1$ and $\delta_{4 \mathrm{j}}=0$. Therefore, the penalty will be: $(1 *(0.1 * 0+0.5 * 0.1 * 1)=0.05$. The penalty is also increased if neither C-138 nor four previous conventions are ratified, in which case $\delta_{4 j}$ $=1$ and the outcome will be: $\left(1^{*}\left(0.1^{*} 1+0.5^{*} 0.1 * 0\right)=0.1\right.$. 
Consider e.g., the case of Cambodia, based on the data used in Cuyvers, Van Den Bulcke and Wijaya (2001). This country had ratified C-138, but not C-182. This means that its $\delta_{138 \mathrm{j}}=0$, but its $\delta_{182 \mathrm{j}}=1$. In addition, Cambodia had not ratified at least four previous conventions on minimum age, so that $\delta_{4 \mathrm{j}}=1$. However, as the country had ratified C-138, the penalty for not having ratified at least four previous conventions would be zero.

The second part of the formula is:

$\left(\delta_{\mathrm{bsj}}\left(\omega_{\mathrm{bs}} \delta_{\mathrm{bfj}}+0.5 \omega_{\mathrm{bs}}\left(1-\delta_{\mathrm{bfj}}\right)\right)\right)$

which relates to the basic working age of 15 or 14 years. In case a country respects 15 years, $\delta_{\mathrm{bsj}}=0$, and it will not be penalized; otherwise it will be equal to 1 . If then the basic working age in that country is below 14 years, $\delta_{\mathrm{bsj}}=1$, but $\delta_{\mathrm{bfj}}=1$, as well, and the penalty will be: $(1 * 0.1 * 1+0.5 * 0.1 * 0)=0.1$. A country will be penalized only half of that if its minimum working age is 14 years, as $\delta_{\mathrm{bsj}}=1$, but $\delta_{\mathrm{bfj}}=0$, which leads to a penalty of $(1 * 0.1 * 0+0.5 * 0.1 * 1)=0.05$.

Again, consider Cambodia, where the basic minimum age, based on the data used in Cuyvers, Van Den Bulcke and Wijaya (2001) was set at 15 years and therefore had a $\delta_{\mathrm{bsj}}=$ 0 and is not penalized. In Guatemala, however, the strict basic working age was 14 years. Therefore, for that country $\delta_{\mathrm{bsj}}=1$, but $\delta_{\mathrm{bfj}}=1$ and the penalty would be 0.1 .

The third part of the FCLI-formula is: $\left(\omega_{1} \delta_{\mathrm{lj}}\right)$ and relates to a country's legal provisions regarding light work. If the minimum age for light work is set at 13 years, $\delta_{\mathrm{lj}}=0$, and no penalty will be applied. However if the minimum age for light work is lower than 13 years, $\delta_{\mathrm{lj}}=1$ and as the weighing coefficient $\omega_{1}=0.1$, the penalty will be 0.1 .

The fourth part of the formula consists of the following:

$\left(\delta_{\mathrm{hsj}}\left(\omega_{\mathrm{hs}} \delta_{\mathrm{hfj}}+0.5 \omega_{\mathrm{hs}}\left(1-\delta_{\mathrm{hfj}}\right)\right)\right)$

and relates to the working age for hazardous work which should be 18 years, or at least 16 or 17 years. This part of the formula functions in an analogous way as the parts relating to the basic minimum working age and the minimum age for light work.

The fifth part of the formula is: $\left(\boldsymbol{\omega}_{\mathrm{e}} \boldsymbol{\delta}_{\mathrm{ej}}\right)$ and tries to capture the age limit provisions in a country about compulsory education. If that age limit equals the basic minimum age, $\delta_{\mathrm{ej}}=$ 0 and no penalty is applied. Otherwise, $\delta_{\mathrm{ej}}=1$, and as the weighing coefficient $\omega_{\mathrm{e}}=0.1$, the penalty for not respecting this part of $\mathrm{C}-138$ equals 0.1 .

The final part of the FCLI-formula only intends to penalize a country if it has not ratified C-182, in which case its $\delta_{182 \mathrm{j}}=1$, and as $\omega_{182}=0.5$, the penalty applied will be 0.5 as well. Contrary, if a country has ratified C-182, $\delta_{182 j}=0$ and no penalty is applied.

\subsubsection{Real Child Labour Index (RCLI) Formula}

The formula that will be used to measure the degree of real respect of C-138 and C-182 is as follows:

$\operatorname{RCLI}_{\mathbf{j}}=1-\operatorname{REA}_{\mathbf{j}}$

with

RCLI $_{\mathrm{j}} \quad=$ Real Child Labour Index of country $\mathrm{j}$ 
REA $_{j}=$ the number of economically active (i.e. working) children in country $\mathrm{j}$ in the age-group of 10-14 year old as a percentage of the total population in this age group.

Hence, the RCLI ranges from zero to one, where a one refers to an absence of child labour (no children between 10 and 14 years of age working) while a zero would mean that all children between 10 and 14 are working in country j. The REA's were obtained by calculating the ratio of the absolute number of working children in the age group of 10 to 14 years and the total population of 10 to 14 years old.

\subsection{The (Composite) Child Labour Index (CLI)}

\section{Formula}

Eventually, a (composite) Child Labour Index can be produced from two elements above by using the following formula:

$$
\begin{array}{ll}
\mathbf{C L I}_{\mathbf{j}}=\boldsymbol{\omega}_{\mathbf{f}} * \mathbf{F C L I}_{\mathbf{j}}+\omega_{\mathbf{r}} * \mathbf{R C L I}_{\mathbf{j}} \\
\text { with } \\
\begin{array}{ll}
\omega_{\mathrm{f}} & =\text { weighing coefficient (0.3) for the FCLI } \\
\omega_{\mathrm{r}} & =\text { weighing coefficient (0.7) for the RCLI } \\
\mathrm{CLI}_{\mathrm{j}} & =\text { the (composite) Child Labour Index } \\
\mathrm{FCLI}_{\mathrm{j}} & =\text { the Formal Child Labour Index } \\
\mathrm{RCLI}_{\mathrm{j}} & =\text { the Real Child Labour Index }
\end{array}
\end{array}
$$

The reader should be pointed out here that the same weights are applied for the formal and the real index as in the calculation of the FAI.

\subsection{Analysis}

The individual FCLI, RCLI and CLI country scores are presented in Appendix 2. Some conclusions can be drawn based on these results. The most serious violations in general, i.e. in the formal and real sense, are apparently to be found in Latin-American developing countries such as Honduras, Guatemala, Colombia and Peru (see Table 2). That Turkey belongs to the Top 5 of scores with the lowest CLI score is of relevance in view of its contribucy for EU membership. On the other hand, the countries that respect C-138 and C182 most, are located in Europe, but also include South-Korea, Canada and the USA. It is rather surprising to find also Sri Lanka among the Top 5 of scores with the highest CLI score. 
Table 2: The top 5 lowest and highest CLI scores

\begin{tabular}{rlll}
\hline \multicolumn{1}{c}{ Top 5 worst CLI scores } & \multicolumn{1}{c}{ Top $\mathbf{5}$ best CLI scores } \\
\hline 1. Ethiopia $(0.43)$ & 1. & $\begin{array}{l}\text { Finland, Ireland, Spain, Switzerland, Malta } \\
(1.00)\end{array}$ \\
2. Honduras (0.65) & 2. & Sri Lanka (0.98) \\
3. Guatemala (0.66) & 3. & Croatia, Italy, New Zealand, Rep. Korea, \\
& Sweden, United States (0.97) \\
4. Turkey (0.73) & 4. & Bahamas (0.96) \\
5. Colombia, Cambodia, Iran, Peru (0.76) & 5. & Canada $(0.94)$ \\
\hline
\end{tabular}

4. Freedom of Gender Discrimination Index (GDI)

Discrimination is defined in the Discrimination Convention (C-111), as follows: 'any distinction, exclusion or preference on the basis of race, color, sex, religion, political opinion, national extraction or social origin, which has the effect of nullifying or impairing equality of opportunity or treatment in employment or occupation' (C-111, art. 1, par. $1(\mathrm{a}))$.

As in Cuyvers, Van Den Bulcke and Wijaya (2001), only gender discrimination is considered. The first international standards on discrimination on grounds of gender focused mainly on women's protection and the role of women as mother as is expressed in the following ILO conventions: the Maternity Protection Convention (C-3, 1919), the Night Work (Women) Convention (C-4, 1919), the Underground Work (Women) Convention (C-45, 1935). In addition, equal remuneration as stipulated by Convention No. 100 also focuses on equality of remuneration between men and women.

\subsection{Methodology}

Factors that should be taken into account when calculating the degree of formal respect a country has towards the relevant ILO conventions are:

\section{Ratification of all relevant ILO conventions}

More in particular the conventions that are fundamental to discrimination should be ratified ('the. fundamental_conventions'), being:

- The Discrimination (in Employment and Occupation) Convention, i.e. C-111, 1958

- The Equal Remuneration Convention, i.e. C-100, 1951 which is part of C-111.

However, there are also other conventions relating to discrimination. The early conventions on discrimination were focused on the protection of women and their role as mother. These conventions will be indicated as the 'traditional-conventions on discrimination' being:

- The Maternity Protection Convention, i.e. C-3, 1919 and C-103, 1952 (revised)

- The Night Work (Women) Convention, i.e. C-4, 1919 and C-41, 1934 \& C-89, 1948 (revised) 
Instead of considering the conventions preceding C-111, the conventions that followed the fundamental convention with respect to discrimination (C-111) can be considered. These conventions will be denoted as 'modern conventions on discrimination' (in short, 'modern conventions'):

- The Workers with Family Responsibilities Convention, i.e. C-156, 1981

- The Part time Work Convention, i.e. C-175, 1994

\section{Submission of reports (in accordance with article 19)}

In order to overcome the problem of establishing a binary index, where one can only distinguish between countries that did or did not ratify, it was decided to establish a criterion to distinguish within the group of non-ratifying countries. For this Article 19 of the constitution of the International Labour Organization is relied on. It invites the Member States that have not yet ratified the convention(s) on discrimination, to submit reports on their legislation with regard to these conventions. In case this report was submitted, in accordance with article 19, the country will be credited for this. Below is given a short description of the contents of the formal gender discrimination index (FGDI) with respective weighing coefficients mentioned between brackets.

\subsection{Gender Discrimination Index (GDI) Formula}

\subsubsection{Formal Gender Discrimination Index (FGDI) Formula}

The formula for the FGDI was constructed as follows:

FGDI $_{\mathrm{j}}=1-\left[\omega_{1}\left(\omega_{111} \delta_{111 \mathrm{j}}+\omega_{100} \delta_{100 \mathrm{j}}\right)+\omega_{2}\left\{\delta_{\mathrm{FGDI}(\mathrm{F}) \mathrm{j}}\left(\omega_{3 / 103} \delta_{3 / 103 \mathrm{j}}+\omega_{4 / 41 / 89} \delta_{4 / 41 / 89 \mathrm{j}}\right.\right.\right.$ $\left.\left.\left.+\omega_{45} \delta_{45 \mathrm{j}}\right)+\left(\omega_{156} \delta_{156 \mathrm{j}}+\omega_{175} \delta_{175 \mathrm{j}}\right)\right\}\right]$

Or in another way:

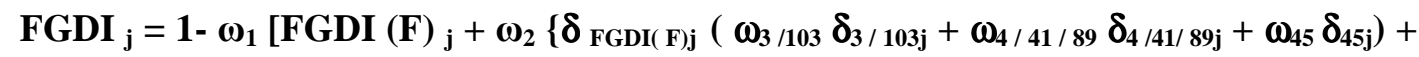
$\left.\left.\left(\omega_{156} \delta_{156 j}+\omega_{175} \delta_{175 j}\right)\right\}\right]$

with

FGDI $\mathrm{j}=$ the formal gender discrimination index of country $\mathrm{j}$

$\operatorname{FGDI}(\mathrm{F}) \mathrm{j}=\omega_{111} \delta_{111 \mathrm{j}}+\omega_{100} \delta_{100 \mathrm{j}}$

$\omega_{1} \quad=$ a weighing coefficient $(0.7)$ relating to $\mathrm{C}-100$ and $\mathrm{C}-111$

$\omega_{2}=$ a weighing coefficient $(0.3)$ relating to C-3, C-4, C-41, C-45, C-89, C-103, $\mathrm{C}-156$ and $\mathrm{C}-175$, in case $\mathrm{C}-100$ and $\mathrm{C}-111$ are not ratified

$\delta_{111 \mathrm{j}}=$ a dummy variable which equals 1 in case of non-ratification of convention 111 with respect to discrimination and equals zero in case country $\mathrm{j}$ did ratify C-111 
$\delta_{100 \mathrm{j}}=$ a dummy variable which equals 1 in case of non-ratification of convention 100 with respect to equal remuneration and equals 0 in case country $\mathrm{j}$ did ratify $\mathrm{C}-100$

$\delta_{\mathrm{FGDI}(\mathrm{F}) \mathrm{j}} \quad=$ a dummy variable which equals 1 in case the two conventions C-111 and C100 were not ratified and equals 0 in case at least one, or both, were ratified. The $\mathrm{F}$ between brackets denotes the two fundamental conventions with respect to discrimination.

$\delta_{3 / 103 \mathrm{j}}=$ a dummy variable equals 1 in case either C-3 or C-103 ( or both ) with respect to the protection of maternity were not ratified and equals 0 in case they were ratified by country $\mathrm{j}$

$\delta_{4 / 41 / 89 \mathrm{j}}=$ a dummy variable that equals 1 in case either C-4, C-41 or C-89 (or all ) with respect to night work for women were not ratified and equals 0 in case they were ratified by country $j$.

$\delta_{45 \mathrm{j}}=$ a dummy variable equals 1 in case of non-ratification of C-45 with respect to underground work for women and equals 0 in case country $\mathrm{j}$ did ratify this convention.

$\delta_{156 \mathrm{j}}=$ a dummy variable equals 1 in case of non-ratification of $\mathrm{C}-156$ with respect to workers with family responsibilities and equals 0 in case country $\mathrm{j}$ did ratify C-156.

$\delta_{175 \mathrm{j}}=$ a dummy variable equals 1 in case of non-ratification of C-175 with respect to part time work and equals 0 in case $\mathrm{C}-175$ was ratified by country $\mathrm{j}$.

$\omega_{111}=$ a weighing coefficient $(0.7)$ for $\mathrm{C}-111$ on discrimination (employment $\&$ occupation )

$\omega_{100} \quad=$ a weighing coefficient $(0.3)$ for C-100 on equality of remuneration

$\omega_{3 / 103}=$ a weighing coefficient $(0.2)$ for $\mathrm{C}-3$ and $\mathrm{C}-103$ with respect to maternity protection

$\omega_{4 / 41 / 89}=$ a weighing coefficient $(0.2)$ for C-4, C-41 and/or C-89 with respect to night work for women

$\omega_{45}=$ a weighing coefficient $(0.2)$ for $\mathrm{C}-45$ with respect to underground work for women

$\omega_{156}=\mathrm{a}$ weighing coefficient $(0.2)$ for $\mathrm{C}-156$ on workers with family responsibilities

$\omega_{175}=$ a weighing coefficient $(0.2)$ for C-175 with respect to part time work

The Formal Freedom of Gender Discrimination Index (FGDI) will be equal to 1 in case of ratification of both conventions (and hence refers to a formal non-discrimination), and equals 0 in case one of the conventions was ratified, which indicates a maximum possible formal degree of discrimination. The FGDI is only higher than 1 in case a particular country has ratified the so-called modern conventions on top of C-100 and C-111, implying in a sense that these countries are getting a "credit" or "negative penalty" for such ratifications. 
The part of the formula: FGDI(F)j $=\omega 111 \delta 111 \mathrm{j}+\omega 100 \delta 100 \mathrm{j}$ only contains dummies relating to the ratification of $\mathrm{C}-111$ and $\mathrm{C}-100$, together with the weights attached. Consider Thailand, which on the basis of the data used in Cuyvers, Van Den Bulcke and Wijaya (2001) had ratified C-111, but not C-100. Taking into account the weights $\operatorname{FGDI}(\mathrm{F}) \mathrm{j}=(0.7 * 1)+(0.3 * 0)=0.7$, which will be deducted from 1 as a first penalty for non-ratification of the two Conventions. This part of the formula is weighted, however, with $\omega 1=0.7$, and therefore the final penalty for Thailand relating to the non-ratification of $\mathrm{C}-100$ will be $0.7 * 0.7=0.49$.

The rest of the formula is:

$\left.\left\{\delta_{\mathrm{FGDI}(\mathrm{F}) \mathrm{j}}\left(\omega_{3 / 103} \delta_{3 / 103 \mathrm{j}}+\omega_{4 / 41 / 89} \delta_{4 / 41 / 89 \mathrm{j}}+\omega_{45} \delta_{45 \mathrm{j}}\right)+\left(\omega_{156} \delta_{156 \mathrm{j}}+\omega_{175} \delta_{175 \mathrm{j}}\right)\right\}\right]$

is weighted with $\boldsymbol{\omega}_{2}=0.3$ and therefore can be considered as consisting of the second and the third part of the formula: $\delta_{\text {FGDI(F)j }}\left(\omega_{3 / 103} \delta_{3 / 103 j}+\omega_{4 / 41 / 89} \delta_{4 / 41 / 89 j}+\omega_{45} \delta_{45 j}\right)$ and $\left(\omega_{156} \delta_{156 \mathrm{j}}+\omega_{175} \delta_{175 \mathrm{j}}\right)$, respectively.

The second part of the formula:

$\delta_{\text {FGDI(F)j }}\left(\omega_{3 / 103} \delta_{3 / 103 j}+\omega_{4 / 41 / 89} \delta_{4 / 41 / 89 j}+\omega_{45} \delta_{45 j}\right)$

intends to capture the respect for the Conventions relating to the protection of maternity, and the protection of women from night work and underground work, in case C-111 and/or $\mathrm{C}-100$ is not ratified. If the country ratified C-111 and/or C-100, the dummy $\delta_{\text {FGDI } \text { F)j }}=0$ and no penalty is applied. However if none of the Conventions is ratified, $\delta_{\mathrm{FGDI}(\mathrm{F}) \mathrm{j}}=1$, and non-ratification of the other Conventions (C-3 and C-103, C-4, C-41, C-89 and C-45 will be considered. Thailand, for instance, again on the basis of the data used in Cuyvers, Van Den Bulcke and Wijaya (2001) had not ratified these conventions, hence $\delta_{3 / 103 j}=\delta_{4 / 41 /}$ ${ }_{89}=\delta_{45 \mathrm{j}}=1$, but as the country ratified C-100, $\delta_{\mathrm{FGDI}(\mathrm{F}) \mathrm{j}}=0$ and therefore the calculated value of its penalty was $0 *[(0.1 * 1)+(0.1 * 1)+(0.1 * 1)]=0$.

The third part of the formula relates to the ratification of the Conventions on respect for workers with family responsibilities and on women and part-time work. The reasoning is the same as before with dummies set at zero in case of ratification and one otherwise.

The FGDI-scores are presented in Appendix 3.

\subsubsection{Real Gender Discrimination Index (RGDI) Formula}

The following formula will be used:

$\operatorname{RGDI}_{\mathbf{j}}=1-\operatorname{ABS}\left[\omega_{\mathrm{ce}}\left(1-\mathrm{F} / \mathrm{M}_{\mathrm{cej}}\right)+\omega_{\mathrm{p}}\left(1-\mathrm{F} / \mathbf{M}_{\mathrm{pj}}\right)+\omega_{\mathrm{w} \mathrm{e}}\left(1-\mathrm{F} / \mathrm{M}_{\mathrm{wej}}\right)+\omega_{\mathrm{w}}\left(1-\mathrm{F} / \mathbf{M}_{\mathrm{wj}}\right)\right]$

with

RGDI $_{\mathrm{j}}=$ real gender discrimination index of country $\mathrm{j}$

ABS = the absolute value of the result of the calculation between square brackets

$\omega_{\mathrm{ce}} \quad=$ weighing coefficient $(0.333)$ for access to education by combined enrolment

$\omega_{\mathrm{p}} \quad=$ weighing coefficient $(0.167)$ for professions

$\omega_{\mathrm{we}} \quad=$ weighing coefficient $(0.167)$ for access to wage employment 
$\omega_{\mathrm{w}} \quad=$ weighing coefficient $(0.333)$ for wage employment

$\mathrm{F} / \mathrm{M}=$ figure of Females in relation to that of Males

1-F/M = gender gap (number 1 indicates total equality)

$\mathrm{F} / \mathrm{M}_{\text {cej }} \quad=$ ratio of the combined female enrolment percentage to the male pct.

$\mathrm{F} / \mathrm{M}_{\mathrm{pj}} \quad=$ ratio of the pct. of female legislators, senior officers etc., to the male pct.

$\mathrm{F} / \mathrm{M}_{\text {wej }} \quad=$ ratio of the pct. of female professional/technical staff, to the male pct.

$\mathrm{F} / \mathrm{M}_{\mathrm{wj}} \quad=$ ratio of the pct. of female paid employment in the female active population, to the male pct.

In short, the real freedom of gender discrimination index will vary from 0 to 1 . A zero indicates total disrespect for the provisions of Convention No. 100 and No. 111. Conversely, a 1 refers to total respect for C-100 and 111, or in other words, total absence of discrimination.

In the formula, extensive use is made of $(1-\mathrm{F} / \mathrm{M})$ as an indicator of discrimination, with $\mathrm{F} / \mathrm{M}$ the ratio of female to male employment or education enrolment, respectively. In some cases this $\mathrm{F} / \mathrm{M}$ ratio is higher than one and therefore $(1-\mathrm{F} / \mathrm{M})<0$, which consequently would increase the final RGDI of the country at issue. What, in fact, is measured is a situation of revealed positive discrimination of women, but equally revealed negative discrimination of men. Therefore, contrary, to the procedure used in Wermenbol, Cuyvers and Van Den Bulcke (1998), Cuyvers, Van Den Bulcke and Wijaya (2001) rather used the absolute value, in which case all, and not only that of women, revealed gender discrimination will lead to a penalty.

The working of the formula is straightforward, although, like before, the weighing coefficients are chosen arbitrarily. If the case of e.g. the Republic of Korea is used as an illustration, the following values for the respective F/M ratios become apparent:

$\begin{array}{ll}\mathrm{F} / \mathrm{M}_{\text {cej }} & =0.895 \\ \mathrm{~F}_{\mathrm{pj}} & =0.33 \\ \mathrm{~F}_{\mathrm{p}} \mathrm{M}_{\text {wej }} & =0.918 \\ \mathrm{~F}_{\mathrm{Fj}} & =0.45\end{array}$

As a result, Korea's RGDI score, based on the data used in Cuyvers, Van Den Bulcke and Wijaya (2001) is: $1-\operatorname{ABS}[0.333 *(1-0.895)+0.167 *(1-0.33)+0.167 *(1-0.918)+0.333 *(1-$ $0.45)=0.66$.

The RGDI scores for selected countries are available in Appendix 3.

\subsubsection{The (Composite) Gender Discrimination Index (GDI) Formula}

Overall performance of a country shall be constructed from the previous two elements i.e. the Formal Gender Discrimination Index (FGDI) and the Real Gender Discrimination Index (RGDI) by using the following formula:

GDI $_{\mathbf{j}}=\omega_{\mathrm{f}} *$ FGDI $_{\mathbf{j}}+\omega_{\mathrm{r}} * \mathbf{R G D I}_{\mathbf{j}}$ 
with

$\omega_{\mathrm{f}} \quad=$ weighing coefficient $(0.3)$ for the formal gender discrimination index

$\omega_{\mathrm{r}} \quad=$ weighing coefficient $(0.7)$ for the real gender discrimination index

GDI ${ }_{j} \quad=$ the (composite) gender discrimination index for country $\mathrm{j}$

FGDI $_{\mathrm{j}} \quad=$ the formal gender discrimination index for country $\mathrm{j}$

$\operatorname{RGDI}_{\mathrm{j}} \quad=$ the real gender discrimination index for country $\mathrm{j}$

Again the same weights are applied for the formal and the real index as in the formulas of FAI and CLI.

\subsection{Analysis}

As revealed by Table 3, developed countries seem to dominate nations with high GDI scores. There are, however, some noteworthy exceptions like Sri Lanka and the Philippines, which are ranked third and fourth among the "Top Five Best Performers", while Ireland is second among the countries with the lowest GDI scores together with Peru.

Table 3: Top Five of Selected Countries for Worst and Best GDI Scores

Top 5 worst GDI scores

1. Togo (0.52)

2. Ireland, Peru (0.54)

3. Guatemala (0.55)

4. Ethiopia (0.58)

5. Indonesia (0.59)
Top 5 best GDI scores

1. Finland (0.94)

2. Macedonia (0.93)

3. Switzerland, Mexico, Spain, Sri Lanka (0.92)

4. Philippines (0.91)

5. Australia (0.90)

\section{The Forced Labour Index}

In constructing a Forced Labour Index, it is important to clearly define forced labour in advance since it is not identical with low-wage labour as many people may seem to think. According to the ILO Convention No.29, forced labour should be defined as "all work or service, which is exacted from any person under the menace of any penalty and for which the said person has not offered himself voluntarily". The ILO's Global Report entitled "Stopping Forced Labour" lists the following main forms of forced labour today:

1. Slavery and abductions,

2. Compulsory participation in public works projects,

3. Coercive recruitment systems in agriculture and remote rural areas,

4. Certain forms of domestic work, 
5. Bonded labour

6. Forced conscription of both children an adults for non military purposes,

7. Trafficking of labour under false pretence,

8. Certain types of prison labour and rehabilitation through work in prison.

There has been almost no country in the world that is not involved in the phenomenon of forced labour, some way or another. On the basis of the sources available, it appears that forced labour exists in both the developing and the developed countries, as well as in the least developed countries.

\subsection{Methodology}

As the Freedom of Association Index, the Child Labour Index, and the Gender Discrimination Index, the Forced Labour Index (FLI) consists of two elements: the Formal Forced Labour Index (FFLI) and the Real Forced Labour Index (RFLI). The Formal Forced Labour Index is developed to assess the legal aspect of a country's compliance in terms of formal respect of the ILO Convention No. 29 Forced Labour Convention and of Convention No. 105 Abolition of Forced Labour Convention.

\subsubsection{The Formal Forced Labour Index (FFLI)}

To construct the Formal Forced Labour Index, the following formula is suggested:

FFLI $=1-\left[\left(\omega_{29} \cdot \delta_{29}\right)+\left(\omega_{105} \cdot \boldsymbol{\delta}_{105}\right)\right]$

where:
$\omega_{29} \quad$ : weight assigned for Convention No. 29 , which is set at 0.5
$\omega_{105} \quad$ : weight assigned for Convention No. 105, which is set at 0.5
$\delta_{29} \quad$ : dummy variable which equals 1 if a country has not ratified ILO Convention No. 29 and equals 0 if the country has ratified that Convention,
$\delta_{105} \quad$ : dummy variable which equals 1 if a country has not ratified ILO Convention No. 105, and equals 0 if the country has ratified that Convention.

FFLI scores are ranging from 0 to 1 . In fact, there are only three possible values that are produced using the above formula: $0,0.5$ and 1 . The score of 0 will be produced when a country has not ratified both conventions; 0.5 if either Convention No. 29 or Convention No. 105 was not ratified; and 1 if both conventions were ratified by the country at issue. It is found that 5 percent of the ILO member states did not ratify either of the forced labour conventions. Consequently, their FFLI score is zero.

\subsubsection{The Real Forced Labour Index (RFLI)}

The Real Forced Labour Index which follows is basically constructed as a measure of forced labour conventions violations as reported in sources whenever available, such as ILO Global Report 2001, http://www.state.gov/, and http://www.icftu.org/. The formula for constructing the index is using data counting, combined with some attempt of a quantification of qualitative aspects of the extent of forced labour involved in particular country. 
The following formula for producing the index for a specific country is proposed:

RFLI $=1-\left[\omega_{\mathrm{q}} \cdot(\Sigma\right.$ FLQ/40 $)+\omega_{\mathrm{t} \cdot}(\Sigma$ FLT/8 $\left.)\right]$

where:

$\Sigma$ FLQ : the sum of the numerically-converted degrees ("quality") of forced labour from any of the 8 type of forced labour (see above) found in the country,

40

: represents the number of numerically converted degrees considered (5, see below) and the number of types of forced labour according to Convention 105 $(8)$,

$\Sigma$ FLT : the sum of types of forced labour that are reportedly found in the country,

8 : number of types of forced labour according to Convention 105,

$\omega_{\mathrm{q}} \quad:$ weight assigned to the quality of forced labour found, which is set at 0.5 ,

$\omega_{\mathrm{t}} \quad:$ weight assigned to number of forced labour type involved, which is set here at 0.5 .

The numerically converted degrees of forced labour are a conversion of 5 levels of the extent of forced labour found in a particular country into a numerical value set as follows (see Table 4):

Table 4: Extent of forced labour and numerical value assigned

\begin{tabular}{|c|c|}
\hline Extent & Value assigned \\
\hline Possible & 1 \\
\hline Exist & 2 \\
\hline Rather serious & 3 \\
\hline Serious & 4 \\
\hline Very Serious & 5 \\
\hline
\end{tabular}

It is typical that the reports on the situation of forced labour in a particular country, no straightforward extent or degree of forced labour is mentioned whatsoever. Therefore a rule of thumb is needed to allow for the determination of the extent of forced labour in the countries at issue, as indicated in Table 5: 
Table 5: Extent of forced labour assigned to reported country situations

\begin{tabular}{ll}
\hline \multicolumn{1}{c}{ Extent } & \multicolumn{1}{c}{ Condition } \\
\hline Possible & $\begin{array}{l}\text { Assigned to a situation for example where a country has national or local legislation } \\
\text { which violates the ILO conventions (C-29 \& C-105) but no reported implementation of } \\
\text { such legislation }\end{array}$ \\
Existing & Assigned to a situation where at least reliable anecdotal evidence is present \\
Rather serious & $\begin{array}{l}\text { Assigned to a situation where forced labour is increasingly becoming a marked trend } \\
\text { rather than merely anecdotal evidence }\end{array}$ \\
Serious & $\begin{array}{l}\text { Assigned to a situation where forced labour cases are spreading out, coupled by poor } \\
\text { efforts to eradicate it }\end{array}$ \\
Assigned to a situation where forced labour is systematically present for instance as a \\
common practice in the country and either no significant progress is seen after efforts \\
are made to abolish it, or no efforts at all are being made
\end{tabular}

The "philosophy" behind the Real Forced Labour Index formula is basically a quantification of the extent of forced labour in a country, combined with the number of types detected in the same country relative to the eight types of forced labour. There are, however, cases that reliable sources are giving a different qualification for the same forced labour situation in a specific country. This can happen e.g., when one source is more keen and specialized in analyzing a certain type of forced labour. Whenever this is the case, a mid-value will be constructed by using the simple average of the quantified degrees assigned by the different sources. Consider, for example, a country with a serious forced labour violation of practicing bonded labour according to source A, but according to another reliable source the situation is deemed to be rather serious. The country will have an RFLI as follows:

Assigned value for "serious" =

Assigned value for "rather serious" = 3

Sum of forced labour quality $(\Sigma F L Q) \quad=(4+3) / 2$

$=3.5$

Sum of type of forced labour involved $(\Sigma$ FLT $) \quad=1$

So the RFLI score for the country is

$$
\begin{aligned}
& =1-[0.5(3.5 / 40)+0.5(1 / 8)] \\
& =1-[0.5 * 0.0875+0.5 * 0.125] \\
& =1-[0.10625]
\end{aligned}
$$

RFLI

$=0.89$

The RFLI calculated scores per country are available in Appendix 4. To illustrate these calculations, consider the following classical instances of forced labour in countries such as India, Bangladesh and Paraguay. According to the sources used in Cuyvers, Van Den Bulcke and Wijaya (2001), India is involved in at least 4 types of forced labour: slavery and abduction, certain types of domestic work, bonded labour and prison labour. The situation seems to be worsened by the apparent extent or degree of forced labour, where the sources are giving qualifications ranging from "existing" (certain types of domestic work and prison labour) to "extremely serious" (bonded labour). This resulted in a low 
RFLI score of 0.59. Similar situations also seem to occur in Bangladesh and Paraguay that show RFLI scores of 0.58 and 0.56 respectively.

\subsubsection{The (Composite) Forced Labour Index}

The composite index of forced labour is constructed by calculating a weighted average of both elements, FFLI and RFLI, with weights assigned of $\omega_{\text {ffli }}$ and $\omega_{\text {rfli }}$, respectively. Hence, the Forced Labour Index (FLI) formula can be written as:

FLI $=\omega_{\text {ffli }}$ FFLI $+\omega_{\text {rfli }} \cdot$ RFLI

with :

FLI : the (Composite) Forced Labour Index

FFLI : the Formal Forced Labour Index

RFLI : the Real Forced Labour Index

$\omega_{\text {ffli }} \quad:$ weight assigned to the Formal Forced Labour Index, which is set at 0,5

$\omega_{\text {rfli }} \quad$ : weight assigned to the Real Forced Labour Index, which is set at 0,5

\subsection{Analysis of FLI}

Appendix 4 presents the FLI scores of the individual countries. The composite FLI scores calculated range between 0.55 and 0.95 . Table 6 shows the "Top 10 Worst Cases" of countries showing the lowest Forced Labour Index score.

Table 6: Top 10 of countries with lowest FLI

\begin{tabular}{|c|c|c|}
\hline Rank & Country & FLI \\
\hline 1 & Nepal & 0,55 \\
\hline 2 & Viet Nam & 0,57 \\
\hline 3 & China & 0,58 \\
\hline 4 & Mongolia & 0,58 \\
\hline 5 & Bolivia & 0,59 \\
\hline 6 & Myanmar & 0,61 \\
\hline 7 & Armenia & 0,63 \\
\hline 8 & Republic of Korea & 0,63 \\
\hline 9 & Equatorial Guinea & 0,64 \\
\hline 10 & Paraguay & 0,69 \\
\hline
\end{tabular}

According Table 6 some remarkable results come forward. That Myanmar, considered as a notorious violator of the forced labour conventions, is on the list of Top 10 Worst Cases, could be expected. However, it is not revealed as the "number one violator", although the international media normally present it as such. According to the available sources, the 
country shows only three types of forced labour involved, compared to e.g., Paraguay, which has five types. There exist, however, other countries with a worse revealed forced labour situation. Although Nepal apparently only applies two types of forced labour, it registers the worst FLI score, i.e. 0.55. However, Nepal's RFLI is 0.78, but since the country did ratify neither Convention No. 29 nor Convention No. 105, this finally led to the lowest score of composite FLI. Hence, according to those tentative calculations, countries that have not ratified any of the forced labour conventions are indeed showing low FLI scores, even if their RFLI scores are relatively higher. Certainly, countries would have lower FLI scores if they did not ratify any conventions and show many types of forced labour with substantial degrees of seriousness, as demonstrated by e.g., India and Bangladesh.

\section{Sensitivity analysis}

Referring to the indices in the Appendix 1-4, it will appear that moving down the ranking list of countries in a number of cases leads to more continuous changes of the indices, while in other cases many ex aequo are found, and shifts and discontinuities are prevalent. For instance, the FFAI takes only values of $1,0.5$ and 0 . The same holds for FFLI. The FGDI seems to be more spread, but still 23 of the 40 countries ranked show a FGDI of 0.88 .

On the other hand, for many countries the RFLI shows less discrete changes than FFLI, but 69 of the 175 countries ranked according to RFAI have an RFAI of 0.7. As a matter of fact, neither the ranking according to "formal" indices, nor that according to "real" indices, should be considered, but rather the combination of both into the FAI, the GDI, the CLI and the FLI.

Another issue is how sensitive the results are for changes in the weights used. In order to check this, the most crucial weights are changed, as summarized in Table $7{ }^{1}$

\footnotetext{
${ }^{1}$ The RCLI was not envisaged here as it contains no weights.
} 
Table 7: Alternative weighting coefficients used in sensitivity analysis

\begin{tabular}{|c|c|c|c|c|c|c|c|c|c|c|c|c|c|c|c|c|c|c|c|}
\hline & $\omega_{87}$ & $\omega_{98}$ & $\omega_{\mathrm{rv}}$ & $\omega_{g i}$ & $\omega \|$ & $\omega_{138}$ & $\omega_{b s}$ & $\omega$ & Whs & $\omega_{\mathrm{e}}$ & $\omega_{182}$ & $\omega_{11}$ & $\omega_{100}$ & $\omega_{c e}$ & $\omega_{p}$ & $\omega_{w \text { e }}$ & $\omega_{w}$ & $\omega_{29}$ & $\omega_{105}$ \\
\hline FFAI & 0.5 & 0.5 & & & & & & & & & & & & & & & & & \\
\hline FFAlbis & 0.3 & 0.7 & & & & & & & & & & & & & & & & & \\
\hline RFAI & & & 0.4 & 0.3 & 0.3 & & & & & & & & & & & & & & \\
\hline RFAlbis & & & 0.8 & 0.1 & 0.1 & & & & & & & & & & & & & & \\
\hline RFAlter & & & 0.2 & 0.4 & 0.4 & & & & & & & & & & & & & & \\
\hline FCLI & & & & & & 0.1 & 0.1 & 0.1 & 0.1 & 0.1 & 0.5 & & & & & & & & \\
\hline FCLIbis & & & & & & 0.5 & 0.1 & 0.1 & 0.1 & 0.1 & 0.1 & & & & & & & & \\
\hline FCLIter & & & & & & 0.2 & 0.2 & 0.1 & 0.1 & 0.2 & 0.2 & & & & & & & & \\
\hline FGDI & & & & & & & & & & & & 0.7 & 0.3 & & & & & & \\
\hline FGDlbis & & & & & & & & & & & & 0.3 & 0.7 & & & & & & \\
\hline FGDIter & & & & & & & & & & & & 0.5 & 0.5 & & & & & & \\
\hline RGDI & & & & & & & & & & & & & & $1 / 3$ & $1 / 6$ & $1 / 6$ & $1 / 3$ & & \\
\hline RGDlbis & & & & & & & & & & & & & & $1 / 2$ & $1 / 4$ & $1 / 4$ & $1 / 2$ & & \\
\hline RGDIter & & & & & & & & & & & & & & $1 / 4$ & $1 / 2$ & $1 / 2$ & $1 / 4$ & & \\
\hline FFLI & & & & & & & & & & & & & & & & & & 0.5 & 0.5 \\
\hline FFLIbis & & & & & & & & & & & & & & & & & & 0.3 & 0.7 \\
\hline FFLIter & & & & & & & & & & & & & & & & & & 0.7 & 0.3 \\
\hline
\end{tabular}

In order to assess, in general terms, the sensitivity of the indices for changes in the weighting coefficients used in their respective formulas, Spearman rank correlation and the Pearson correlation between the relevant alternatives were calculated. These correlation coefficients are shown in Table 8 and Table 9.

With two exceptions, the correlation coefficients are larger than 0.5. These exceptions are Pearson correlation between FCLI and FCLIbis, and the Pearson correlation coefficient between FLI and FLIbis. In fact, the vast majority of the coefficients in Table 8 and 9 are larger than 0.7. All, except one, are significant at the $1 \%$ level (the significance level is even higher than $0.001 \%$ ). The exception here is the Pearson correlation coefficient between FCLI and FCLIbis, but even there the coefficients are significant at the $2.5 \%$ level.

The strange low correlation between FCLI and FCLIbis is likely to be due to the fact that the ratification data used in the calculation of the formal child labour index are these of the year 2000, i.e. only one year after the launch of C-182, when hardly 16 of the 40 countries considered had ratified it, against 38 who had ratified $\mathrm{C}-138$. Today, the ratification records of C-138 and C-182 are much more comparable. But, not surprisingly, if the 2000 data are used and five times more weight is given to the ratification record of $\mathrm{C}-182$ than to that of C-138, it will have a large impact on the FCLI. 
The relatively lower correlation between FLI and FLIbis, however, seems to indicate that that index, in particular the formal forced labour index, needs further refinement. The weights attached to the ratification of C-29 and C-105, in combination with the dummies in the FFLI formula, result in a calculated FFLI which takes only three values, i.e., 1, 0.5 and 0 , with 1 for 146 of the 175 countries, and 0.5 for only 21 countries.

With the exception of the FFLI, it can be concluded that varying the weights in the formulas is not having much impact on the ranking of the countries. In all cases, the degree of association between the indices and their variants remains consistently high. 


\begin{tabular}{|c|c|c|c|c|c|c|c|c|c|c|c|c|c|c|c|}
\hline & FFAlbis & RFAlbis & RFAlter & CLlbis & CLlter & FCLlbis & FCLlter & GDlbis & GDIter & FGDIbis & FGDIter & RGDlbis & RGDIter & FLlbis & FLlter \\
\hline FFAI & $1.00^{\star \star \star}$ & & & & & & & & & & & & & & \\
\hline RFAl & & $0.79^{\star \star \star}$ & $0.97^{\star \star \star}$ & & & & & & & & & & & & \\
\hline RFAlbis & & & $0.72^{\star \star \star}$ & & & & & & & & & & & & \\
\hline CLI & & & & $0.99^{* \star *}$ & $0.97^{\star \star \star}$ & & & & & & & & & & \\
\hline CLIbis & & & & & $0.99^{* * *}$ & & & & & & & & & & \\
\hline FCLI & & & & & & $0.70^{\star \star \star}$ & $0.92^{\star \star \star}$ & & & & & & & & \\
\hline FCLlbis & & & & & & & $0.84^{\star \star *}$ & & & & & & & & \\
\hline GDI & & & & & & & & $0.97^{\star \star \star}$ & $0.94^{\star \star \star}$ & & & & & & \\
\hline GDlbis & & & & & & & & & $0.98^{\star \star \star}$ & & & & & & \\
\hline FGDI & & & & & & & & & & $1.00^{\star \star \star}$ & $1.00^{\star \star *}$ & & & & \\
\hline FGDlbis & & & & & & & & & & & $1.00^{\star * *}$ & & & & \\
\hline RGDI & & & & & & & & & & & & $1.00^{\star \star \star}$ & $0.91^{\star \star \star}$ & & \\
\hline RGDlbis & & & & & & & & & & & & & $0.91^{\star \star \star}$ & & \\
\hline FLI & & & & & & & & & & & & & & $0.58^{\star \star \star}$ & $0.97^{\star \star \star}$ \\
\hline FLlbis & & & & & & & & & & & & & & & $0.67^{\star \star \star}$ \\
\hline${ }^{* \star}$ significa & level $>0.025$ & & & & & & & & & & & & & & \\
\hline
\end{tabular}


Table 9 : Pearson correlation coefficients between social respect indices and their alternatives

\begin{tabular}{lccc}
\hline & FFAlbis & RFAlbis & RFAlte \\
\hline FFAl & $0.98^{* \star *}$ & & \\
RFAl & & $0.87^{\star * \star}$ & $0.98^{* \star *}$ \\
RFAlbis & & & $0.74^{* \star *}$
\end{tabular}

CLI

$0.96^{\star \star \star} \quad 0.90^{\star \star \star}$

CLlbis

$0.99^{\star * *}$

FCLI

$0.40^{\star \star} \quad 0.83^{\star \star \star}$

FCLlbis

$0.73^{* \star \star}$

GDI

$0.92^{\star \star \star} \quad 0.67^{\star \star \star}$

GDlbis

FGDI

FGDIbis

$0.98^{\star * \star}$

$0.98^{\star \star \star}$

RGDI

$1.00^{\star \star \star} \quad 0.94^{\star \star \star}$

RGDlbis

$0.94^{\star \star \star}$

FLI

$0.50^{\star \star \star} \quad 0.71^{\star \star \star}$

FLlbis

$0.68^{\star \star \star}$

** significance level $>0.025$

*** significance level $>0.01$ 


\section{References}

Cuyvers, L., Van Den Bulcke, D. and Wijaya, C. (2001). Quantifying respect for selected core labor standards with special emphasis on forced labor, Report prepared for the International Labour Office, Contract No. 11305, Project Code O.055.10.900.812, University of Antwerp, December 2001.

Heritage Foundation (2004). 2004 Index of Economic Freedom, at http://www.heritage.org/research/features/index/.

ILO (2001). ILO Global Report - Stopping Forced Labour, International Labour Office. Geneva.

IMD (2004). World Competitiveness Yearbook 2004, at: http://www01.imd.ch/wcy/ranking/.

Political and Economic Risk Consultancy (2001). Corruption in Asia in 2001, at:http://www.asiarisk.com/lib10.html.

The Economist (2004). The Big Mac Index, at: http://www.economist.com/markets/Bigmac/Index.cfm.

UNDP (2003). Human Development Report 2003, at: http://hdr.undp.org/reports/global/2003/pdf/hdr03_HDI.pdf.

Wermenbol, G., Cuyvers, L. and Van Den Bulcke, D. (1998). Proposal for a Social Development Index - Respect for ILO core labour standards against the background of the implementation capacity of countries, VL.I.R Research project, Belgian Administration of Development Co-operation (ABOS), Antwerp: University of Antwerp, January 1998. 


\section{APPENDICES}


Appendix 1: Freedom of Association Index and its sub-indices

\begin{tabular}{|c|c|c|c|}
\hline Country & FFAl & RFAl & FAI \\
\hline Australia & 1,00 & 0,70 & 0,79 \\
\hline Bahamas & 1,00 & 0,70 & 0,79 \\
\hline Bahrain & 0,00 & 1,00 & 0,70 \\
\hline Brazil & 0,50 & 0,91 & 0,79 \\
\hline Cambodia & 1,00 & 0,68 & 0,78 \\
\hline Canada & 0,50 & 1,00 & 0,85 \\
\hline Colombia & 1,00 & 0,14 & 0,40 \\
\hline Costa Rica & 1,00 & 0,66 & 0,76 \\
\hline Croatia & 1,00 & 0,67 & 0,77 \\
\hline El Salvador & 0,00 & 0,96 & 0,67 \\
\hline Ethiopia & 1,00 & 0,65 & 0,76 \\
\hline Finland & 1,00 & 0,70 & 0,79 \\
\hline Georgia & 1,00 & 0,58 & 0,71 \\
\hline Greece & 1,00 & 0,70 & 0,79 \\
\hline Guatemala & 1,00 & 0,71 & 0,80 \\
\hline Honduras & 1,00 & 0,78 & 0,85 \\
\hline Indonesia & 1,00 & 0,52 & 0,67 \\
\hline the Islamic Republic of Iran & 0,00 & 0,98 & 0,69 \\
\hline Ireland & 1,00 & 0,70 & 0,79 \\
\hline Italy & 1,00 & 0,70 & 0,79 \\
\hline Kazakhstan & 1,00 & 0,70 & 0,79 \\
\hline Republic of Korea & 0,00 & 0,82 & 0,58 \\
\hline Lithuania & 1,00 & 0,70 & 0,79 \\
\hline The former Yugoslav Republic of Macedonia & 1,00 & 0,70 & 0,79 \\
\hline Malta & 1,00 & 0,56 & 0,69 \\
\hline Mexico & 0,50 & 0,95 & 0,82 \\
\hline Morocco & 0,50 & 0,46 & 0,47 \\
\hline New Zealand & 0,00 & 0,96 & 0,67 \\
\hline Nicaragua & 1,00 & 0,83 & 0,88 \\
\hline Peru & 1,00 & 0,81 & 0,87 \\
\hline Philippines & 1,00 & 0,56 & 0,69 \\
\hline Slovenia & 1,00 & 0,49 & 0,64 \\
\hline Spain & 1,00 & 0,70 & 0,79 \\
\hline Sri Lanka & 1,00 & 0,78 & 0,85 \\
\hline Sweden & 1,00 & 0,70 & 0,79 \\
\hline Switzerland & 1,00 & 0,91 & 0,94 \\
\hline Thailand & 0,00 & 0,64 & 0,45 \\
\hline Togo & 1,00 & 0,69 & 0,78 \\
\hline Turkey & 1,00 & 0,73 & 0,81 \\
\hline United States & 0,00 & 0,96 & 0,67 \\
\hline
\end{tabular}


Appendix 2: Freedom of Child Labour Index and its sub-indices

\begin{tabular}{|c|c|c|c|}
\hline Country & FCLI & RCLI & CLI \\
\hline Australia & 0,45 & 1,00 & 0,84 \\
\hline Bahamas & 0,85 & 1,00 & 0,96 \\
\hline Bahrain & 0,75 & 1,00 & 0,93 \\
\hline Brazil & 0,95 & 0,83 & 0,87 \\
\hline Cambodia & 0,30 & 0,95 & 0,76 \\
\hline Canada & 0,80 & 1,00 & 0,94 \\
\hline Colombia & 0,25 & 0,97 & 0,76 \\
\hline Costa Rica & 0,40 & 0,95 & 0,78 \\
\hline Croatia & 0,90 & 1,00 & 0,97 \\
\hline El Salvador & 0,95 & 0,88 & 0,90 \\
\hline Ethiopia & 0,35 & 0,46 & 0,43 \\
\hline Finland & 1,00 & 1,00 & 1,00 \\
\hline Georgia & 0,30 & 1,00 & 0,79 \\
\hline Greece & 0,50 & 1,00 & 0,85 \\
\hline Guatemala & 0,35 & 0,80 & 0,66 \\
\hline Honduras & 0,25 & 0,83 & 0,65 \\
\hline Indonesia & 0,95 & 0,91 & 0,92 \\
\hline the Islamic Republic of Iran & 0,30 & 0,96 & 0,76 \\
\hline Ireland & 1,00 & 1,00 & 1,00 \\
\hline Italy & 0,90 & 1,00 & 0,97 \\
\hline Kazakhstan & 0,40 & 1,00 & 0,82 \\
\hline Republic of Korea & 0,90 & 1,00 & 0,97 \\
\hline Lithuania & 0,30 & 1,00 & 0,79 \\
\hline The former Yugoslav Republic of Macedonia & 0,40 & 1,00 & 0,82 \\
\hline Malta & 1,00 & 1,00 & 1,00 \\
\hline Mexico & 0,75 & 0,89 & 0,85 \\
\hline Morocco & 0,70 & 0,94 & 0,87 \\
\hline New Zealand & 0,90 & 1,00 & 0,97 \\
\hline Nicaragua & 0,85 & 0,89 & 0,88 \\
\hline Peru & 0,30 & 0,96 & 0,76 \\
\hline Philippines & 0,90 & 0,92 & 0,91 \\
\hline Slovenia & 0,40 & 1,00 & 0,82 \\
\hline Spain & 1,00 & 1,00 & 1,00 \\
\hline Sri Lanka & 1,00 & 0,97 & 0,98 \\
\hline Sweden & 0,90 & 1,00 & 0,97 \\
\hline Switzerland & 1,00 & 1,00 & 1,00 \\
\hline Thailand & 0,70 & 0,91 & 0,85 \\
\hline Togo & 0,85 & $\mathrm{n} / \mathrm{a}$ & $\mathrm{n} / \mathrm{a}$ \\
\hline Turkey & 0,40 & 0,87 & 0,73 \\
\hline United States & 0,90 & 1,00 & 0,97 \\
\hline
\end{tabular}


Appendix 3: Freedom of Gender Discrimination Index and its sub-indices

\begin{tabular}{|c|c|c|c|}
\hline Country & FGDI & RGDI & GDI \\
\hline Australia & 0,94 & 0,88 & 0,90 \\
\hline Bahamas & 0,88 & 0,72 & 0,77 \\
\hline Bahrain & 0,67 & 0,61 & 0,63 \\
\hline Brazil & 0,88 & 0,83 & 0,84 \\
\hline Cambodia & 0,88 & 0,51 & 0,62 \\
\hline Canada & 0,88 & 0,89 & 0,88 \\
\hline Colombia & 0,88 & 0,80 & 0,82 \\
\hline Costa Rica & 0,88 & 0,73 & 0,78 \\
\hline Croatia & 0,94 & 0,83 & 0,87 \\
\hline El Salvador & 0,94 & 0,71 & 0,78 \\
\hline Ethiopia & 0,94 & 0,42 & 0,58 \\
\hline Finland & 1,00 & 0,92 & 0,94 \\
\hline Georgia & 0,88 & 0,65 & 0,72 \\
\hline Greece & 0,94 & 0,76 & 0,81 \\
\hline Guatemala & 0,94 & 0,38 & 0,55 \\
\hline Honduras & 0,88 & 0,62 & 0,70 \\
\hline Indonesia & 0,88 & 0,47 & 0,59 \\
\hline the Islamic Republic of Iran & 0,88 & 0,39 & 0,54 \\
\hline Ireland & 0,88 & 0,82 & 0,84 \\
\hline Italy & 0,94 & 0,78 & 0,83 \\
\hline Kazakhstan & 0,88 & 0,86 & 0,87 \\
\hline Republic of Korea & 0,94 & 0,66 & 0,74 \\
\hline Lithuania & 0,88 & 0,94 & 0,92 \\
\hline The former Yugoslav Republic of Macedonia & 0,94 & 0,72 & 0,79 \\
\hline Malta & 0,88 & 0,64 & 0,71 \\
\hline Mexico & 0,88 & 0,71 & 0,76 \\
\hline Morocco & 0,88 & 0,40 & 0,54 \\
\hline New Zealand & 0,88 & 0,93 & 0,91 \\
\hline Nicaragua & 0,88 & 0,49 & 0,61 \\
\hline Peru & 0,94 & 0,61 & 0,71 \\
\hline Philippines & 0,88 & 0,94 & 0,92 \\
\hline Slovenia & 1,00 & 0,88 & 0,92 \\
\hline Spain & 0,94 & 0,77 & 0,82 \\
\hline Sri Lanka & 0,88 & 0,94 & 0,92 \\
\hline Sweden & 0,94 & 0,92 & 0,93 \\
\hline Switzerland & 0,88 & 0,71 & 0,76 \\
\hline Thailand & 0,39 & 0,70 & 0,61 \\
\hline Togo & 0,88 & 0,37 & 0,52 \\
\hline Turkey & 0,88 & 0,53 & 0,64 \\
\hline United States & 0,00 & 0,92 & 0,64 \\
\hline
\end{tabular}


Appendix 4: Freedom of Forced Labour Index and its sub-indices

\begin{tabular}{|c|c|c|c|}
\hline Country & FFLI & RFLI & FLI \\
\hline Australia & 1,00 & 0,84 & 0,89 \\
\hline Bahamas & 1,00 & $\mathrm{n} / \mathrm{a}$ & $\mathrm{n} / \mathrm{a}$ \\
\hline Bahrain & 1,00 & 0,78 & 0,84 \\
\hline Brazil & 1,00 & 0,68 & 0,78 \\
\hline Cambodia & 1,00 & 0,89 & 0,92 \\
\hline Canada & 0,50 & 0,83 & 0,73 \\
\hline Colombia & 1,00 & 0,79 & 0,86 \\
\hline Costa Rica & 1,00 & 0,91 & 0,94 \\
\hline Croatia & 1,00 & 0,91 & 0,94 \\
\hline El Salvador & 1,00 & 0,91 & 0,94 \\
\hline Ethiopia & 0,50 & $\mathrm{n} / \mathrm{a}$ & $\mathrm{n} / \mathrm{a}$ \\
\hline Finland & 1,00 & 0,91 & 0,94 \\
\hline Georgia & 1,00 & 0,90 & 0,93 \\
\hline Greece & 1,00 & 0,81 & 0,87 \\
\hline Guatemala & 1,00 & 0,71 & 0,80 \\
\hline Honduras & 1,00 & 0,83 & 0,88 \\
\hline Indonesia & 1,00 & 0,65 & 0,76 \\
\hline the Islamic Republic of Iran & 1,00 & 0,93 & 0,95 \\
\hline Ireland & 1,00 & 0,93 & 0,95 \\
\hline Italy & 1,00 & 0,90 & 0,93 \\
\hline Kazakhstan & 1,00 & 0,89 & 0,92 \\
\hline Republic of Korea & 0,00 & 0,90 & 0,63 \\
\hline Lithuania & 1,00 & 0,89 & 0,92 \\
\hline The former Yugoslav Republic of Macedonia & 0,50 & 0,90 & 0,78 \\
\hline Malta & 1,00 & $\mathrm{n} / \mathrm{a}$ & $\mathrm{n} / \mathrm{a}$ \\
\hline Mexico & 1,00 & 0,79 & 0,85 \\
\hline Morocco & 1,00 & 0,81 & 0,87 \\
\hline New Zealand & 1,00 & 0,83 & 0,88 \\
\hline Nicaragua & 1,00 & 0,79 & 0,85 \\
\hline Peru & 1,00 & 0,78 & 0,84 \\
\hline Philippines & 0,50 & 0,83 & 0,73 \\
\hline Slovenia & 1,00 & 0,91 & 0,94 \\
\hline Spain & 1,00 & 0,83 & 0,88 \\
\hline Sri Lanka & 0,50 & 0,82 & 0,72 \\
\hline Sweden & 1,00 & 0,91 & 0,94 \\
\hline Switzerland & 1,00 & 0,91 & 0,94 \\
\hline Thailand & 1,00 & 0,82 & 0,87 \\
\hline Togo & 1,00 & 0,65 & 0,76 \\
\hline Turkey & 1,00 & 0,90 & 0,93 \\
\hline United States & 0,50 & 0,83 & 0,73 \\
\hline
\end{tabular}




\section{Policy Integration Department Working Papers}

No. 1 ILO activities on the social dimension of globalization: Synthesis report

No. 2 Measuring decent work with statistical indicators

Richard Anker, Igor Chernyshev, Philippe Egger, Farhad Mehran and Joseph Ritter

No. 3 Globalization and decent work: Options for Panama Philippe Egger

No. 4 Globalización y trabajo decente: Opciones para Panamá Philippe Egger

No. 5 Indicators of social dialogue: Concepts and measurements Lane Kenworthy and Bernhard Kittel

No. 6 Assessing the impact of the attacks of 11 September 2001 on women's employment in the United States

Gertrude Schaffner Goldberg and Helen Lachs Ginsburg

No. 7 Decent work and the informal economy in Central America Juan Diego Trejos Solórzano and Miguel Del Cid

No. 8 Poverty initiatives in the ILO: A review of past and present approaches Pat Holden and Dagmar Walter

No. 9 Whither the International Standard Classification of Occupations (ISCO-88)? Debbie Budlender

No. 10 Improving occupational classifications as tools for describing labour markets:

A summary of recent national experiences

Debbie Budlender

No. 11 Recent developments in China's labour economy

Thomas G. Rawski

No. 12 The Impact of economic liberalization on employment and wages in India Sonia Bhalotra

No. 13 The impact of trade liberalization upon inequality in developing countries Donald J. Robbins

No. 14 The impact of liberalization and globalization on income inequality in developing and transitional economies

Giovanni Andrea Cornia

No. 15 The impact of technology transfer on employment and income distribution in developing countries: A survey of theoretical models and empirical studies

Mariacristina Piva 


\section{Policy Integration Department Working Papers \\ Prepared by the World Commission on the \\ Social Dimension of Globalization}

No. 16 International finance: Meeting the needs of people in developing countries José Guilherme Almeida dos Reis

No. 17 The gender dimensions of globalization of production Stephanie Barrientos, Naila Kabeer and Naomi Hossain

No. 18 Social exclusion in the context of globalization - Jan Breman

No. 19 Gender and globalization: A macroeconomic perspective Çağatay Nilüfer and Ertük Korkurt

No. 20 Globalization, social exclusion, and work: with special reference to informal employment and gender - Marilyn Carr and Martha Chen

No. 21 Resources for social development - Antony Clunies Ross

No. 22 Does the new international trade regime leave room for industrialization policies in the middle-income countries? - Alisa DiCaprio and Alice Amsden

No. 23 Social dimension of globalization in Latin America: Lessons from Bolivia and Chile, Ivaro García Hurtado

No. 24 The social dimension of globalization: a review of the literature Bernhard Gunter and Rolph van der Hoeven

No. 25 The social dimension of global production systems: A review of the issues, Susan Hayter

No. 26 Reforming global economic and social governance: a critical review of recent programmatic thinking - Jeremy Heimans

No. 27 Corporate social responsibility: an issues paper - Michael Hopkins

No. $28 \quad$ Upgrading in global value chains - John Humphrey

No. 29 Implications of globalization and economic restructuring for skills development in Sub-Saharan Africa - Richard K. Johanson

No. 30 The outcome and impact of the main international commissions on development issues Frédéric Lapeyre

No. 31 Globalization and structural adjustment as a development tool - Frédéric Lapeyre

No. 32 Globalization and perceptions of social inequality - Malte Luebker

No. 33 The changing structure of international trade linked to global production systems: what are the policy implications? - William Milberg

No. 34 Corporate social responsibility: an overview of principles and practice,Jill Murray

No. 35 Inclusive development strategy in an era of globalization - Ignacy Sachs

No. 36 Social consequences of the globalization of the media and communication sector: some strategic considerations - Seán Ó. Siochrú

No. 37 Globalization, history and international migration: a view from Latin America Andrés Solimano

No. 38 Towards a different kind of globalization, or how the anti-globalists view the world Gijsbert van Liemt 


\section{Policy Integration Department Working Papers}

No. 39 How do trade union rights affect trade competitiveness?

David Kucera and Ritash Sarna

No. 40 Statistics on the employment situation of people with disabilities:

A compendium of national methodologies

ILO Bureau of Statistics in collaboration with the In Focus Programme on Skills,

Knowledge and Employability

No. 41 Employment in the informal economy in the Republic of Moldova

ILO Bureau of Statistics in collaboration with the Department for Statistics and Sociology of the Republic of Moldova

No. 42 Decent work in a least developed country: A critical assessment of the Ethiopia PRSP Graeme J. Buckley

No. 43 Unemployment and Labour Market Institutions:

The Failure of the Empirical Case for Deregulation

Dean Baker, Andrew Glyn, David Howell and John Schmitt

No. 44 Women's access to occupations with authority, influence and decision-making power: Women as legislators, senior officials and managers around the world Richard Anker.

No. 45 The world of work in the context of economic integration and trade liberalization Daniel Martínez

No. 46 Poverty reduction in Pakistan: The strategic impact of macro and employment policies Moazam Mahmood

No. 47 Trends in Work Stoppages: A Global Perspective

L. J. Perry and Patrick J. Wilson

No. 48 Generating decent work for poverty reduction in Cambodia:

The voice of workers, employers and the Government Moazam Mahmood

No. 49 The Social Dimension of Regional Integration in ECOWAS René Robert

No. 50 Measuring trade union rights: A country-level indicator constructed from coding violations recorded in textual sources

David Kucera

No. 51 Patterns of job quality attributes in European Union Joseph A. Ritter

No. 52 Child Labour, Education and Export Performance

David Kucera and Ritash Sarna 
No. 53 Measuring the informal economy: From employment in the informal sector to informal employment

Ralf Hussmanns

No. 54 Indicators of labour standards: an overview and comparison

Richard N. Block

No. 55 The pattern of globalization and some implications for the pursuit of social goals Gerry Rodgers

No. 56 Statistical indicators of social dialogue: A compilation of multiple country databases Anne Chataigner

No. 57 Trade unions and informal workers' associations in the urban informal economy of Ecuador - Catherine Vaillancourt-Laflamme

No. 58 Decent work, standards and indicators

Monique Zarka-Martres and Monique Guichard-Kelly

No. 59 Social Dialogue Indicators: Trade Union Membership and Collective Bargaining Coverage, Statistical Concepts, Methods and Findings

Sophia Lawrence and Junko Ishikawa

No. 60 Informality and Gender in Latin America

María Elena Valenzuela

No. 61 Labour developments in dynamic Asia: What do the data show?

David Kucera and Anne Chataignier

No. 62 Sources and Methods: Labour Statistics - Volume 5: Total and economically active population, employment and unemployment (Population censuses), Third edition

No. 63 Desarrollo local en América Latina: Oportunidades y desafíos para el trabajo decente Francisco Alburquerque

No. 64 Bangladesh Decent Work statistical indicators: a fact-finding study Mustafa K. Mujeri

No. 65 The impact of globalization on poverty in Bangladesh S. R. Osmani

No. 66 International Labour Migration from Bangladesh: a decent work perspective Tasneem Siddiqui

No. 67 Globalization and Decent Work: a report for the Decent Work Pilot Programme in Bangladesh Sukti Dasgupta and Amelita King Dejardin

No. 68 East Africa Reduction poverty and gender inequality: Selected strategies and issues

No. 69 Sources et méthodes: statistiques du travail - Volume 5 : Population totale et active, emploi et chômage (Recensements de population), Troisième édition

No. 70 Fuentes y Métodos: Estadísticas del Trabajo - Volumen 5: Población total y económicamente activa, empleo y desempleo (Censos de población ), Tercera edición 
No. 71 The quantification of respect for selected core labour standards: towards a social development index?

Ludo Cuyvers and Daniel Van Den Bulcke 